\title{
THE SOURCE OF THE ESPINHAÇO DIAMONDS: EVIDENCES FROM SHRIMP U-PB ZIRCON AGES OF THE SOPA CONGLOMERATE AND PB-PB ZIRCON EVAPORATION AGES OF METAVOLCANIC ROCKS
}

\author{
MARIO LUIZ DE SÁ CARNEIRO CHAVES ${ }^{1}$, TÂNIA MARA DUSSIN ${ }^{2}$ AND YUJI SANO 3
}

\begin{abstract}
We present here the results of the SHRIMP U/Pb zircon ages obtained from the diamond-bearing Sopa Conglomerate and also $\mathrm{Pb}-\mathrm{Pb}$ zircon evaporation age of the associated metavolcanic rocks, outcropping in the Diamantina region of the Espinhaço Range. The Sopa Conglomerate, a clast-supported rock that appear in the lower part of the Espinhaço Supergroup, was deposited mainly in alluvial fan, braided river and fan delta systems. The apparent ${ }^{238} \mathrm{U}_{-}{ }^{206} \mathrm{~Pb}$ and ${ }^{207} \mathrm{~Pb}-{ }^{206} \mathrm{~Pb}$ zircon ages varied from $1442 \mathrm{Ma}$ to $3683 \mathrm{Ma}$ and from $1726 \mathrm{Ma}$ to 3599 Ma peaks, respectively. Different generations of zircon populations showed by the radiometric ages surely demonstrate the age of cratonic rocks, however it is still unknown if one of them could be correlated with a primary source rock of the diamonds. The series of K- and Fe-rich metavolcanics is coeval with the Sopa Conglomerate. The results of a single date of these rocks yielded ages of $1710 \pm 12 \mathrm{Ma}$ to the crystallization of the volcanic protolith. Detrital zircons of the Sopa Conglomerate matrix are older than the primary zircons of the metavolcanic rocks outcropping in the lower Espinhaço Supergroup. Therefore, geochronological data do not provide additional evidence for the idea that diamonds are originated from these metavolcanic rocks, as supposed by some authors after geologic regional studies.
\end{abstract}

Keywords: zircon ages, diamond, Sopa Conglomerate, Espinhaço metavolcanics.

INTRODUCTION The São Francisco Craton in Eastern Brazil, one of the major shield areas forming the South American platform, had its present-day configuration defined by the remobilization of its edges during the Brasiliano Orogeny in the Neoproterozoic. This tectonic cycle produced deformation and closure of the Paleo- to Neoproterozoic basins represented in the neighboring cratonic regions. In the southeast boundary area of the craton, the Espinhaço Supergroup, a thick metasedimentary rift sequence, represents one of these basins.

Lithostratigraphy and depositional aspects of the Espinhaço Supergroup in Diamantina region (Minas Gerais) has been the subject of several studies, partially motivated by the diamond-bearing conglomerates (the "Sopa" Conglomerate) that it contains. However, studies concerning zircon ages of these conglomerates and comparisons with other regional zircon ages, such as those of the hematite phyllite, a rare metavolcanic rock occurring in the basal portion of the Espinhaço Supergroup (considered by some authors the source of the diamonds of Espinhaço region), are missing. We present here the results of the SHRIMP U/Pb zircon ages obtained from the Sopa Conglomerate, and comparisons with the available data from zircons of other related rocks and their importance for the knowledge of the enigmatic source of the diamonds in the region.

GEOLOGIC SETTING In the southeastern part of the São Francisco Craton, overlying the Archean basement represented by gneiss, migmatites, granites and ancient Paleoproterozoic sequences (Minas Supergroup and correlative sequences), the Espinhaço rifting took place. A NS-trending trough, from Quadrilátero Ferrífero northwards, cutting the craton, more than $1000 \mathrm{~km}$ long and $50-100 \mathrm{~km}$ wide, was formed. About $3000 \mathrm{~m}$ of sediments forming the Espinhaço Supergroup were deposited around $1.75 \mathrm{Ga}$ (Dossin et al. 1990 , Uhlein 1991, Schobbenhaus 1993). Carbonatic and clastic metasediments of Neoproterozoic age (the São Francisco Supergroup) overlap the Espinhaço Supergroup and its basement (Fig. 1).

Thick quartzitic beds, with conglomerate, phyllite and sericite schist intercalations, constitute the Espinhaço Supergroup (Schöll and Fogaça 1979, Garcia and Uhlein 1987, Dossin et al. 1990). These metasediments have been divided into eight or nine formations (e.g. Pflug 1968, Almeida-Abreu 1993), grouped in the Diamantina and Conselheiro Mata groups (Dossin et al. 1990). The basal sequence (Diamantina Group), a series of fluvial to neritic clastic sediments, was deposited during the principal rifting phase. The sedimentary features, especially the frequency and rapidity of the faciologic variations, indicate a great instability that characterized this period. These sediments were covered by the aeolian sediments that record the end of the crustal instability, and correspond to the upper part of the sequence. Towards the top of the supergroup, and to the west of the sedimentary basin, the Conselheiro Mata Group characterizes a period of
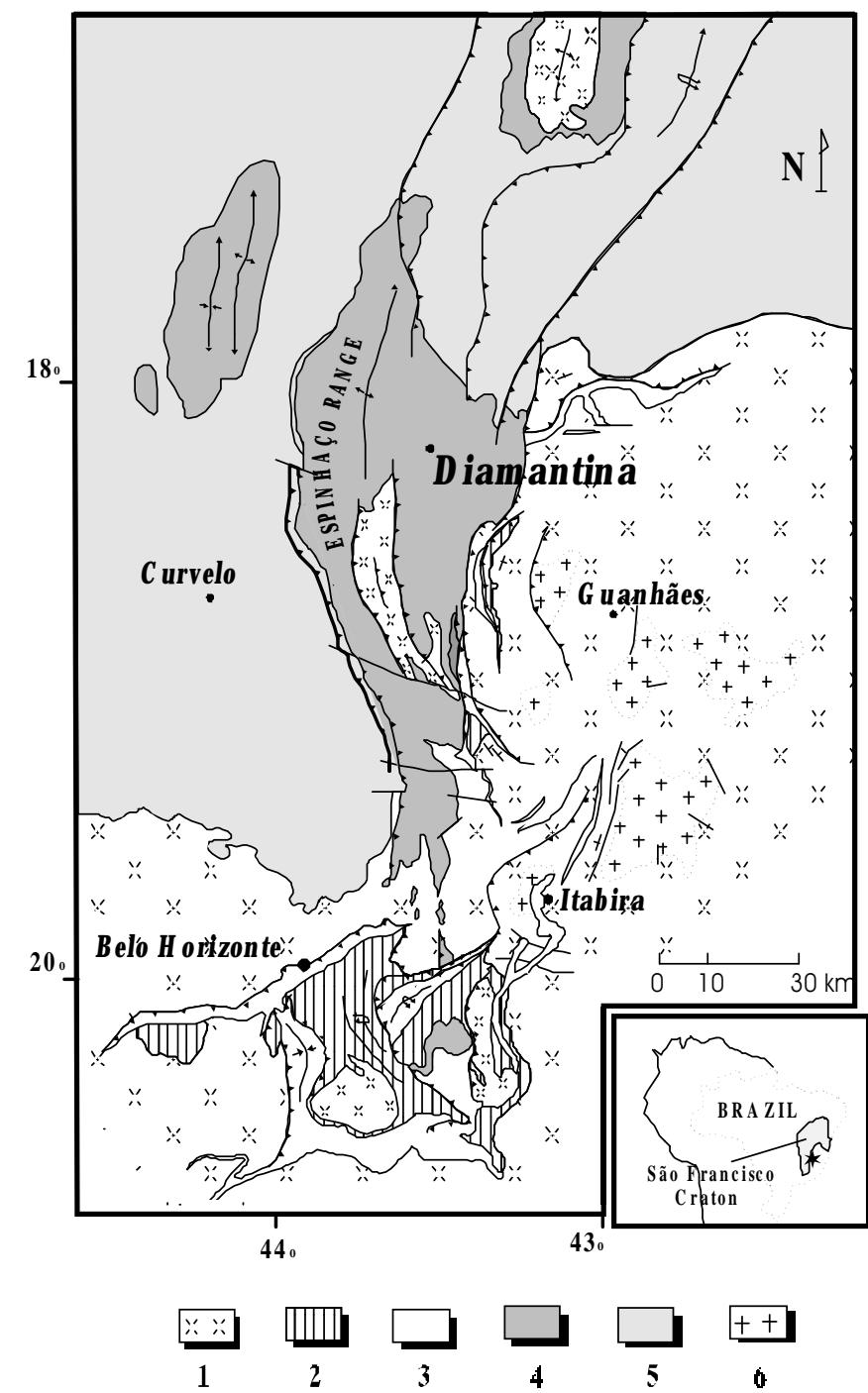

Figure 1 - Schematic geologic map of the Southern Espinhaço Range and Quadrilatero Ferrifero regions, southeastern São Francisco Craton. 1Archean basement, 2- Volcanic-sedimentary sequences, 3-Minas Supergroup, 4- Espinhaço Supergroup, 5- São Francisco Supergroup, 6- Granites.

1 - Instituto de Geociências e Grupo de Estudos de Mineralogia (GEMA) do Museu de História Natural, Universidade Federal de Minas Gerais, Rua Gustavo da Silveira 1035, CEP 31.080-010, Belo Horizonte, MG, Brasil. FAX (31)499-5410. E-mail mchaves@igc.ufmg.br

2 - Instituto de Geociências e Centro de Pesquisas Prof. Manoel Teixeira da Costa, Universidade Federal de Minas Gerais, Av. Antônio Carlos 6627, CEP 31270901, Belo Horizonte, MG, Brasil. E-mail dussin@ dedalus.lcc.ufmg.br

3 - Dept of Earth and Planetary Sciences, Hiroshima University, Kagami-yama 1-3, Higashi-Hiroshima, 739-8526, Japan. E-mail ysano@ipc.hiroshima-u.ac.jp 
transgressive sedimentation. Quartzites, phyllites, metasiltstones, and dolomites in the upper portions, constitute the unit.

The diamond-bearing Sopa Conglomerate, a clast-supported rock with a variable argillaceous to coarse-grained sandy matrix, appears in the lower part of the Diamantina Group. The clasts are predominantly intraformational including metasandstone, phyllite, breccia, conglomerate, quartz, and volcanic rocks. Clasts of well-rounded quartz vein are the extraformational source, occurring on variable proportions (1-40\%) in the deposits. Locally also occur rare extraformational clasts of iron-formation, talc schist, and fuchsite-rich quartzite. Common heavy minerals in the matrix are hematite, magnetite, rutile and kyanite, all of metamorphic origin, while rare zircon and diamond are detrital (Chaves 1997). The Sopa Conglomerate, the oldest known diamondiferous rock in the Diamantina region, was deposited mainly in alluvial fan, braided river and fan delta systems.

Metavolcanic rocks also appear in the lower Diamantina Group, interbedded with or cutting the continental sedimentary sequence; they correspond mainly to sericite- and Fe-rich rocks named as "hematite phyllites". The stratigraphic relationships indicate that the volcanism occurred at an early stage of sedimentation as flows and filling in vertical NS and EW dykes that cut the basement, and seems to have been active during a short period of time, fading as sedimentation rates increased. Plutonic associations are unknown and there are no other magmatic rocks obviously associated to onset of the sedimentation in the region.

The metasedimentary and metavolcanic rocks of the Espinhaço Supergroup and its basement were deformed during the Brasiliano Orogeny at about 650-550 Ma (e.g. Uhlein et al. 1986, Marshak and Alkmin 1989, Uhlein 1991). The associated metamorphism is of greenschist facies. Rocks deformed under ductile conditions in the eastern regions of the belt, grade into non-deformed rocks towards the interior of the São Francisco Craton, to the west. The metamorphic conditions also decrease parallel to the deformation from east to west. In the zones of high stress, recrystallization has obliterated some primary minerals in all rocks.

\section{ZIRCON AGES FROM THE SOPA CONGLOMERATE}

Zircon and other heavy minerals were separated from the diamondbearing Sopa Conglomerate, using standard crushing and heavy-liquid techniques. U-Pb age determinations by SHRIMP (Sensitive High Resolution Ion Microprobe) were carried out at Hiroshima University, Japan. Zircon grains were mounted in epoxy with other several grains of standard zircons "QGNG". QGNG is a new multicrystal zircon standard from quartz-gabbro-norite-gneiss from Cape Donnington, Eyre Peninsula, South Australia whose TIMS (thermal ionization mass spectrometry method) $\mathrm{U} / \mathrm{Pb}$ age is $1850 \pm 2 \mathrm{Ma}$.

Subtraction of common $\mathrm{Pb}$ from measured $\mathrm{Pb}$ was required to estimate the accurate age. In this study, the measured ${ }^{208} \mathrm{~Pb} /{ }^{206} \mathrm{~Pb}$ ratio in each grain was used for the correction of common $\mathrm{Pb}$ with a single stage evolution model with ${ }^{238} \mathrm{U} /{ }^{204} \mathrm{~Pb}=8.8$ and ${ }^{232} \mathrm{Th} /{ }^{238} \mathrm{U}=3.8$ (Compston et al. 1984). When we take a two-stage evolution model for common $\mathrm{Pb}$ (Stacey and Kramers 1975), the correct ages are consistent within experimental error. This method is effective for low $\mathrm{Th} / \mathrm{U}$ samples such as zircon. Although ${ }^{204} \mathrm{~Pb} /{ }^{206} \mathrm{~Pb}$ was measured to confirm the presence of common $\mathrm{Pb}$, the correction of common $\mathrm{Pb}$ using ${ }^{204} \mathrm{~Pb} /{ }^{206} \mathrm{~Pb}$ causes a large analytical uncertainly because of the low ${ }^{204} \mathrm{~Pb}$ abundance.

Table 1 lists U concentrations, ${ }^{204} \mathrm{~Pb} /{ }^{206} \mathrm{~Pb},{ }^{207} \mathrm{~Pb} /{ }^{206} \mathrm{~Pb},{ }^{208} \mathrm{~Pb} /$ ${ }^{206} \mathrm{~Pb},{ }^{238} \mathrm{U} /{ }^{206} \mathrm{~Pb}$ ratios and apparent ${ }^{238} \mathrm{U} /{ }^{206} \mathrm{~Pb}$ and ${ }^{238} \mathrm{U} /{ }^{206} \mathrm{~Pb}$ ages from 76 spots on 70 zircon grains from four mines in the "Sopa" diamond-bearing conglomerate. Sub-numbers such as DAT28.01 and DAT28.02 indicates different pit positions in a single grain, where 01 shows the rim part of zircon and 02 is the core. $U$ concentrations vary significantly from $22 \mathrm{ppm}$ to $488 \mathrm{ppm}$ with the average of $122 \pm 84$ ppm. The apparent ${ }^{238} \mathrm{U}_{-}{ }^{206} \mathrm{~Pb}$ and ${ }^{207} \mathrm{~Pb}-{ }^{206} \mathrm{~Pb}$ ages vary from 1442 Ma to 3683 Ma and from 1726 Ma to 3599 Ma, respectively. Most zircons are concordant except for some samples such as LCG521.01, RGU561.01 and RGU594.01. Note that these discordant zircons have relatively large $U$ concentrations. The core parts of some zircons (LCG521 and LCG528) show ${ }^{238} \mathrm{U}_{-}{ }^{206} \mathrm{~Pb}$ ages older than rim part but the other zircons (DAT28 and DAT36) have a similar age between core and rim.

Figure 2 shows a ${ }^{238} \mathrm{U}_{-}{ }^{206} \mathrm{~Pb}^{*}$ and ${ }^{207} \mathrm{~Pb}^{206} \mathrm{~Pb}^{*}$ correlation diagram for zircon, where "**" indicates radiogenic components (Tera and
Wasserburg 1972). There are three major U-Pb ages, about 2.1 Ga, 2.7 $\mathrm{Ga}$ and $2.9 \mathrm{Ga}$ besides two concordant outliers with about $1.7 \mathrm{Ga}$ and 3.6 Ga. A least squares fitting by using Isoplot/Ex (Ludwig 1998) to the first discordant zircon group yields the upper and lower concordia intercept ages of $2151 \pm 17$ Ma and $811 \pm 160$ Ma with MSWD=1.4, respectively. The second and third groups indicate the upper and lower ages of $2692 \pm 20 \mathrm{Ma}$ and $2931 \pm 22 \mathrm{Ma}$, and $562 \pm 380 \mathrm{Ma}$ and 803 $\pm 110 \mathrm{Ma}$ with MSWD=1.9 and 2.1, respectively. It is noted that the lower concordia intercept ages of the three zircon groups agree at about $800 \mathrm{Ma}$.

\section{CHEMISTRY AND AGE OF THE HEMATITE PHYLLITES}

Hematite phyllites have been recently analyzed and dated by Dussin (1994). Geochemical features of these rocks are displayed in Figure 3. Major elements of these rocks show high contents of $\mathrm{K}_{2} \mathrm{O}$ (4.5 to $9.2 \%), \mathrm{TiO}_{2}$ (4.0 to $6.7 \%$ ), $\mathrm{Al}_{2} \mathrm{O}_{3}$ (18.5 to $23.8 \%$ ), $\mathrm{FeO}^{2}$ (16.78 to $37.05 \%)$, and low contents of $\mathrm{SiO}_{2}$ (28.3 to $\left.40.7 \%\right), \mathrm{Na}_{2} \mathrm{O}$ (0.1 to $1.5 \%), \mathrm{CaO}(<1.7 \%)$ and $\mathrm{MgO}$ (traces to $8.5 \%)$. These compositions are also much apart from usual igneous rocks to reflect original magmatic protolith. They are the result of lixiviation of the most mobile elements with relative enrichment of those that had a more immobile behavior during alteration.

Some of the trace elements, especially $\mathrm{Sr}, \mathrm{Ba}$ and $\mathrm{P}$, show a large range of compositions as a reflection of their greater mobility. Other elements as $\mathrm{Zr}, \mathrm{Y}, \mathrm{Nb}$ and $\mathrm{REE}$, however, seem to have had a restricted or less significant mobility. These elements have absolute concentrations rather similar in all analyzed samples and the ratios among them are possibly close to the magmatic ones. The less mobile element contents suggest that the hematite phyllites represent an alkaline magmatism related to the onset of intracratonic rifting processes (Fig. 3).

The apparent absence of suitable lithological types has precluded the use of conventional geochronological methods for dating the rocks of the Espinhaço Supergroup. The characterization of volcanic rocks associated with the initial phases of basin formation fill in this gap. Selected zircons from the hematite phyllites have been used for isotopic analyses by step-wise direct $\mathrm{Pb}$ evaporation. This method yields ${ }^{207} \mathrm{~Pb} /{ }^{206} \mathrm{~Pb}$ age determinations (technique and method of age calculations according to Kober 1987, and Cocherie et al. 1992).

The preliminary results of this study were presented by Dossin $\mathrm{et} \mathrm{al}$. (1993). Complete analytical results and data of a zircon geomorphologic study are in Dussin (1994). The analyses show a marked $\mathrm{Pb}$-loss at the borders of the grains, but ${ }^{207} \mathrm{~Pb} /{ }^{206} \mathrm{~Pb}$ ratio is stable in the inner parts of the crystals, which yielded similar ages around $1700 \mathrm{Ma}$. This age is confirmed by two grains showing reduced or no $\mathrm{Pb}$-loss and yielding three step-age of $1710 \pm 12 \mathrm{Ma}$, calculated using 109 determinations of ${ }^{207} \mathrm{~Pb} / 206 \mathrm{~Pb}$ ratios (Table 2 and Fig. 4). This age is considered as dating the magmatic crystallization.

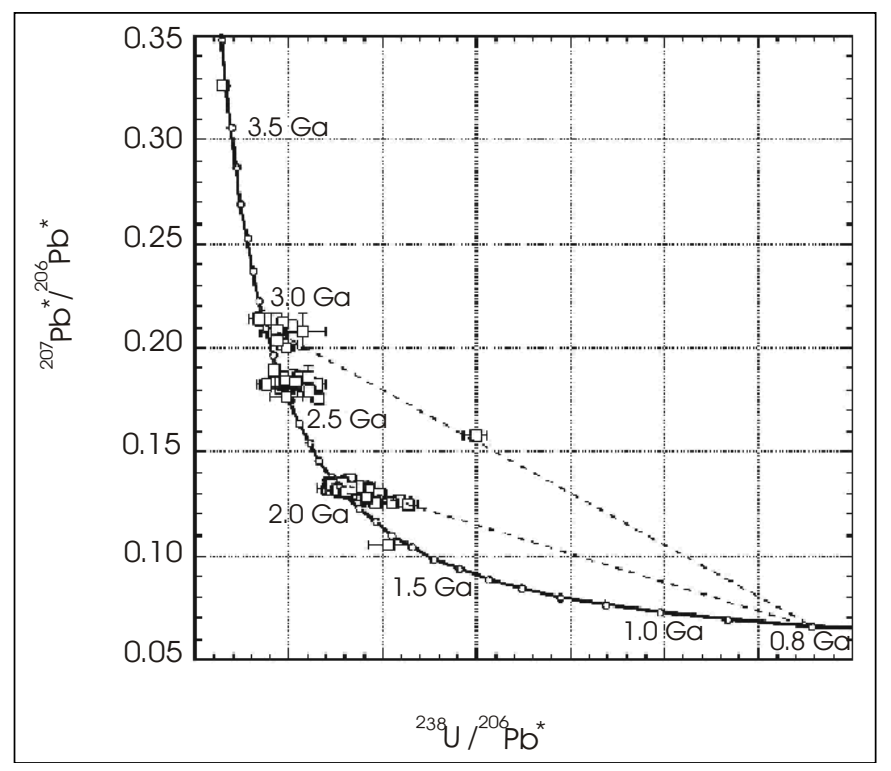

Figure $2-{ }^{238} U-{ }^{206} \mathrm{~Pb} *$ and ${ }^{207} \mathrm{~Pb}-{ }^{206} \mathrm{~Pb} *$ correlation diagram for zircon from the Sopa Conglomerate (“*” indicates radiogenic components). 
Table 1-Representative U-Pb analyses of zircons from the diamond-bearing Sopa Conglomerate in Diamantina region (Minas Gerais). Localities DAT= Datas de Cima mine, $R G U=$ Guinda River mine, $L C G=$ Lavrinha mine, SER=Serrinha mine (according to Sano et al. 2000 ).

\begin{tabular}{|c|c|c|c|c|c|c|c|}
\hline \multicolumn{2}{|c|}{ Sample/ U (ppm) } & ${ }^{204} \mathrm{~Pb} /{ }^{206} \mathrm{~Pb}$ & ${ }^{201} \mathrm{~Pb} /{ }^{206} \mathrm{~Pb}$ & ${ }^{208} \mathrm{~Pb} /{ }^{206} \mathrm{~Pb}$ & ${ }^{238} \mathrm{U} /{ }^{206} \mathrm{~Pb}$ & ${ }^{238} \mathrm{U} /{ }^{206} \mathrm{~Pb}$ age & ${ }^{200} \mathrm{~Pb} /{ }^{206} \mathrm{~Pb}$ age \\
\hline DAT28.01 & 88 & $0.001233 \pm 0.000207$ & $0.1472 \pm 0.0019$ & $0.1286 \pm 0.0028$ & $2.629 \pm 0.123$ & $2038 \pm 82$ & $2110 \pm 52$ \\
\hline DAT28.02 & 85 & $0.000045 \pm 0.000026$ & $0.1331 \pm 0.0010$ & $0.0899 \pm 0.0010$ & $2.721 \pm 0.163$ & $2016 \pm 104$ & $2131 \pm 14$ \\
\hline DAT30.01 & 79 & $0.000013 \pm 0.000017$ & $0.1839 \pm 0.0011$ & $0.4916 \pm 0.0029$ & $1.836 \pm 0.096$ & $2803 \pm 119$ & $2687 \pm 10$ \\
\hline DAT33.01 & 280 & $0.000015 \pm 0.000007$ & $0.1256 \pm 0.0007$ & $0.1331 \pm 0.0007$ & $2.939 \pm 0.140$ & $1888 \pm 78$ & $2035 \pm 10$ \\
\hline DAT34.01 & 176 & $0.000019 \pm 0.000011$ & $0.1296 \pm 0.0008$ & $0.1468 \pm 0.0009$ & $2.741 \pm 0.147$ & $2005 \pm 92$ & $2089 \pm 11$ \\
\hline DAT36.01 & 35 & $0.000060 \pm 0.000052$ & $0.1818 \pm 0.0013$ & $0.6519 \pm 0.0041$ & $1.982 \pm 0.106$ & $2631 \pm 115$ & $2663 \pm 14$ \\
\hline DAT36.02 & 27 & $0.000118 \pm 0.000054$ & $0.1821 \pm 0.0020$ & $0.5298 \pm 0.0060$ & $1.903 \pm 0.081$ & $2718 \pm 94$ & $2659 \pm 20$ \\
\hline DAT37.01 & 61 & $0.000073 \pm 0.000038$ & $0.1831 \pm 0.0012$ & $0.5945 \pm 0.0040$ & $2.073 \pm 0.104$ & $2535 \pm 105$ & $2673 \pm 12$ \\
\hline DAT39.01 & 92 & $0.000013 \pm 0.000015$ & $0.2106 \pm 0.0012$ & $0.0839 \pm 0.0010$ & $1.842 \pm 0.107$ & $2796 \pm 132$ & $2909 \pm 10$ \\
\hline DAT41.01 & 202 & $0.000013 \pm 0.000010$ & $0.1826 \pm 0.0010$ & $0.2309 \pm 0.0016$ & $1.760 \pm 0.105$ & $2900 \pm 139$ & $2676 \pm 09$ \\
\hline DAT45.01 & 96 & $0.000028 \pm 0.000025$ & $0.1305 \pm 0.0011$ & $0.1155 \pm 0.0012$ & $2.669 \pm 0.158$ & $2051 \pm 104$ & $2110 \pm 15$ \\
\hline DAT46.01 & 129 & $0.000222 \pm 0.000029$ & $0.2101 \pm 0.0023$ & $0.2964 \pm 0.0028$ & $1.833 \pm 0.141$ & $2798 \pm 174$ & $2886 \pm 18$ \\
\hline DAT47.01 & 49 & $0.000035 \pm 0.000018$ & $0.2144 \pm 0.0032$ & $0.3333 \pm 0.0016$ & $1.857 \pm 0.130$ & $2776 \pm 158$ & $2639 \pm 24$ \\
\hline DAT48.01 & 128 & $0.000022 \pm 0.000008$ & $0.2018 \pm 0.0010$ & $0.1261 \pm 0.0059$ & $1.941 \pm 0.141$ & $2678 \pm 160$ & $2839 \pm 08$ \\
\hline DAT53.01 & 110 & $0.000065 \pm 0.000014$ & $0.2098 \pm 0.0015$ & $0.0902 \pm 0.0012$ & $1.898 \pm 0.161$ & $2726 \pm 189$ & $2898 \pm 11$ \\
\hline DAT54.01 & 226 & $0.000030 \pm 0.000011$ & $0.1843 \pm 0.0011$ & $0.0951 \pm 0.0008$ & $2.067 \pm 0.223$ & $2543 \pm 227$ & $2688 \pm 10$ \\
\hline RGU558.01 & 163 & $0.000050 \pm 0.000018$ & $0.1343 \pm 0.0008$ & $0.2305 \pm 0.0021$ & $2.811 \pm 0.106$ & $1960 \pm 64$ & $2146 \pm 11$ \\
\hline RGU559.01 & 97 & $0.000057 \pm 0.000032$ & $0.1828 \pm 0.0018$ & $0.4935 \pm 0.0038$ & $2.305 \pm 0.097$ & $2321 \pm 82$ & $2672 \pm 16$ \\
\hline RGU561.01 & 240 & $0.000041 \pm 0.000013$ & $0.1269 \pm 0.0006$ & $0.2582 \pm 0.0013$ & $3.178 \pm 0.108$ & $1763 \pm 52$ & $2048 \pm 09$ \\
\hline RGU562.01 & 91 & $0.000003 \pm 0.000009$ & $0.2004 \pm 0.0020$ & $0.2263 \pm 0.0025$ & $1.983 \pm 0.064$ & $2633 \pm 70$ & $2829 \pm 16$ \\
\hline RGU564.01 & 83 & $0.000064 \pm 0.000040$ & $0.2041 \pm 0.0018$ & $0.0738 \pm 0.0011$ & $1.872 \pm 0.049$ & $2756 \pm 59$ & $2854 \pm 15$ \\
\hline RGU565.01 & 90 & $0.000012 \pm 0.000023$ & $0.1314 \pm 0.0015$ & $0.2059 \pm 0.0030$ & $2.577 \pm 0.067$ & $2113 \pm 47$ & $2115 \pm 21$ \\
\hline RGU566.01 & 174 & $0.000031 \pm 0.000014$ & $0.2151 \pm 0.0008$ & $0.2349 \pm 0.0014$ & $1.756 \pm 0.045$ & $2904 \pm 60$ & $2942 \pm 06$ \\
\hline RGU567.01 & 147 & $0.000092 \pm 0.000038$ & $0.1373 \pm 0.0008$ & $0.2190 \pm 0.0016$ & $2.613 \pm 0.059$ & $2086 \pm 40$ & $2178 \pm 13$ \\
\hline RGU569.01 & 83 & $0.000002 \pm 0.000020$ & $0.1857 \pm 0.0013$ & $0.5224 \pm 0.0034$ & $1.932 \pm 0.063$ & $2689 \pm 71$ & $2704 \pm 11$ \\
\hline RGU571.01 & 91 & $0.000077 \pm 0.000044$ & $0.1903 \pm 0.0016$ & $0.1207 \pm 0.0019$ & $1.841 \pm 0.045$ & $2794 \pm 55$ & $2736 \pm 15$ \\
\hline RGU584.01 & 113 & $0.000025 \pm 0.000015$ & $0.2161 \pm 0.0017$ & $0.0915 \pm 0.0020$ & $1.766 \pm 0.041$ & $2892 \pm 54$ & $2949 \pm 13$ \\
\hline RGU585.01 & 178 & $0.000042 \pm 0.000039$ & $0.1333 \pm 0.0011$ & $0.1300 \pm 0.0020$ & $2.603 \pm 0.062$ & $2094 \pm 43$ & $2135 \pm 17$ \\
\hline RGU589.01 & 202 & $0.000069 \pm 0.000028$ & $0.1265 \pm 0.0011$ & $0.2896 \pm 0.0025$ & $3.103 \pm 0.064$ & $1799 \pm 32$ & $2036 \pm 16$ \\
\hline RGU591.01 & 95 & $0.000020 \pm 0.000029$ & $0.1326 \pm 0.0015$ & $0.2678 \pm 0.0038$ & $2.819 \pm 0.062$ & $1956 \pm 37$ & $2129 \pm 21$ \\
\hline RGU592.01 & 78 & $0.000052 \pm 0.000071$ & $0.2109 \pm 0.0026$ & $0.2502 \pm 0.0052$ & $2.021 \pm 0.059$ & $2590 \pm 62$ & $2908 \pm 22$ \\
\hline RGU593.01 & 41 & $0.000328 \pm 0.000147$ & $0.1344 \pm 0.0020$ & $0.1466 \pm 0.0028$ & $2.831 \pm 0.098$ & $1940 \pm 58$ & $2099 \pm 41$ \\
\hline RGU594.01 & 235 & $0.000008 \pm 0.000021$ & $0.1297 \pm 0.0014$ & $0.2229 \pm 0.0022$ & $2.966 \pm 0.069$ & $1873 \pm 38$ & $2092 \pm 20$ \\
\hline LCG521.01 & 468 & $0.001188 \pm 0.000093$ & $0.1731 \pm 0.0009$ & $0.1197 \pm 0.0030$ & $3.902 \pm 0.126$ & $1442 \pm 42$ & $2434 \pm 19$ \\
\hline LCG521.02 & 184 & $0.000143 \pm 0.000009$ & $0.1806 \pm 0.0011$ & $0.0290 \pm 0.0007$ & $2.221 \pm 0.129$ & $2391 \pm 116$ & $2642 \pm 11$ \\
\hline LCG522.01 & 61 & $0.000048 \pm 0.000009$ & $0.1336 \pm 0.0012$ & $0.0919 \pm 0.0017$ & $2.612 \pm 0.159$ & $2088 \pm 109$ & $2137 \pm 16$ \\
\hline LCG522.02 & 66 & $0.000032 \pm 0.000011$ & $0.1329 \pm 0.0011$ & $0.0862 \pm 0.0013$ & $2.412 \pm 0.112$ & $2235 \pm 88$ & $2131 \pm 15$ \\
\hline LCG524.01 & 65 & $0.000046 \pm 0.000006$ & $0.1361 \pm 0.0014$ & $0.1368 \pm 0.0012$ & $2.434 \pm 0.078$ & $2217 \pm 60$ & $2170 \pm 17$ \\
\hline LCG525.01 & 69 & $0.000061 \pm 0.000088$ & $0.1328 \pm 0.0013$ & $0.1905 \pm 0.0028$ & $2.849 \pm 0.075$ & $1937 \pm 44$ & $2124 \pm 25$ \\
\hline LCG525.02 & 93 & $0.000019 \pm 0.000005$ & $0.1320 \pm 0.0008$ & $0.2222 \pm 0.0017$ & $2.460 \pm 0.076$ & $2199 \pm 58$ & $2121 \pm 11$ \\
\hline LCG526.01 & 166 & $0.000015 \pm 0.000002$ & $0.1839 \pm 0.0013$ & $0.5687 \pm 0.0030$ & $1.923 \pm 0.098$ & $2699 \pm 112$ & $2687 \pm 12$ \\
\hline LCG528.01 & 206 & $0.000003 \pm 0.000006$ & $0.2123 \pm 0.0017$ & $0.2203 \pm 0.0013$ & $1.934 \pm 0.044$ & $2687 \pm 50$ & $2923 \pm 13$ \\
\hline LCG528.02 & 105 & $0.000005 \pm 0.000001$ & $0.2142 \pm 0.0008$ & $0.1710 \pm 0.0010$ & $1.751 \pm 0.089$ & $2913 \pm 119$ & $2937 \pm 06$ \\
\hline LCG529.01 & 89 & $0.000018 \pm 0.000002$ & $0.2143 \pm 0.0039$ & $0.1637 \pm 0.0028$ & $1.677 \pm 0.110$ & $3014 \pm 158$ & $2937 \pm 29$ \\
\hline LCG531.01 & 55 & $0.000020 \pm 0.000004$ & $0.3264 \pm 0.0014$ & $0.1484 \pm 0.0014$ & $1.297 \pm 0.062$ & $3683 \pm 133$ & $3599 \pm 06$ \\
\hline LCG533.01 & 30 & $0.000031 \pm 0.000013$ & $0.1345 \pm 0.0010$ & $0.1573 \pm 0.0016$ & $2.453 \pm 0.084$ & $2203 \pm 64$ & $2152 \pm 13$ \\
\hline LCG534.01 & 80 & $0.000015 \pm 0.000007$ & $0.1322 \pm 0.0009$ & $0.1198 \pm 0.0009$ & $2.521 \pm 0.100$ & $2153 \pm 73$ & $2125 \pm 12$ \\
\hline LCG536.01 & 101 & $0.000040 \pm 0.000007$ & $0.1850 \pm 0.0017$ & $0.5089 \pm 0.0034$ & $1.944 \pm 0.073$ & $2674 \pm 82$ & $2694 \pm 15$ \\
\hline LCG538.01 & 85 & $0.000049 \pm 0.000009$ & $0.1334 \pm 0.0010$ & $0.1911 \pm 0.0013$ & $2.593 \pm 0.118$ & $2101 \pm 81$ & $2134 \pm 14$ \\
\hline SER56.01 & 248 & $0.000263 \pm 0.000039$ & $0.1353 \pm 0.0005$ & $0.1952 \pm 0.0010$ & $2.755 \pm 0.110$ & $1988 \pm 68$ & $2122 \pm 11$ \\
\hline SER57.01 & 88 & $0.000000 \pm 0.000207$ & $0.1846 \pm 0.0009$ & $0.1019 \pm 0.0007$ & $2.097 \pm 0.067$ & $2514 \pm 67$ & $2695 \pm 08$ \\
\hline SER60.01 & 149 & $0.000004 \pm 0.000002$ & $0.1832 \pm 0.0006$ & $0.4566 \pm 0.0021$ & $2.077 \pm 0.085$ & $2533 \pm 86$ & $2682 \pm 05$ \\
\hline SER61.01 & 81 & $0.000105 \pm 0.000027$ & $0.1330 \pm 0.0010$ & $0.2782 \pm 0.0018$ & $2.672 \pm 0.072$ & $2046 \pm 47$ & $2119 \pm 14$ \\
\hline SER62.01 & 111 & $0.000045 \pm 0.000014$ & $0.1333 \pm 0.0008$ & $0.1327 \pm 0.0009$ & $2.724 \pm 0.122$ & $2014 \pm 77$ & $2134 \pm 11$ \\
\hline SER63.01 & 48 & $0.000009 \pm 0.000016$ & $0.1348 \pm 0.0029$ & $0.1666 \pm 0.0043$ & $2.582 \pm 0.114$ & $2110 \pm 80$ & $2160 \pm 37$ \\
\hline SER64.01 & 91 & $0.000040 \pm 0.000015$ & $0.1313 \pm 0.0007$ & $0.1403 \pm 0.0009$ & $2.620 \pm 0.088$ & $2083 \pm 60$ & $2108 \pm 10$ \\
\hline SER67.01 & 134 & $0.000028 \pm 0.000009$ & $0.2093 \pm 0.0016$ & $0.1363 \pm 0.0012$ & $1.884 \pm 0.090$ & $2743 \pm 106$ & $2898 \pm 13$ \\
\hline SER68.01 & 88 & $0.000000 \pm 0.000012$ & $0.1330 \pm 0.0007$ & $0.1585 \pm 0.0012$ & $2.742 \pm 0.104$ & $2005 \pm 65$ & $2138 \pm 10$ \\
\hline SER69.01 & 119 & $0.000000 \pm 0.000012$ & $0.1255 \pm 0.0008$ & $0.3757 \pm 0.0016$ & $2.932 \pm 0.075$ & $1892 \pm 42$ & $2036 \pm 11$ \\
\hline SER70.01 & 50 & $0.000081 \pm 0.000053$ & $0.1335 \pm 0.0008$ & $0.0885 \pm 0.0014$ & $2.674 \pm 0.092$ & $2045 \pm 61$ & $2131 \pm 15$ \\
\hline SER71.01 & 226 & $0.000313 \pm 0.000033$ & $0.1290 \pm 0.0005$ & $0.1459 \pm 0.0013$ & $3.254 \pm 0.104$ & $1719 \pm 48$ & $2027 \pm 10$ \\
\hline SER72.01 & 103 & $0.000065 \pm 0.000030$ & $0.1293 \pm 0.0009$ & $0.2371 \pm 0.0012$ & $2.823 \pm 0.109$ & $1953 \pm 65$ & $2077 \pm 14$ \\
\hline SER73.01 & 42 & $0.000107 \pm 0.000042$ & $0.1764 \pm 0.0014$ & $0.4917 \pm 0.0035$ & $2.309 \pm 0.077$ & $2316 \pm 65$ & $2607 \pm 15$ \\
\hline SER74.01 & 62 & $0.000053 \pm 0.000019$ & $0.1868 \pm 0.0048$ & $0.1113 \pm 0.0023$ & $2205 \pm 0.065$ & $2409 \pm 59$ & $2709 \pm 42$ \\
\hline
\end{tabular}


Table 2-Isotopic data from single-grain evaporation on the Fe-rich metavolcanics from Espinhaço Supergroup.

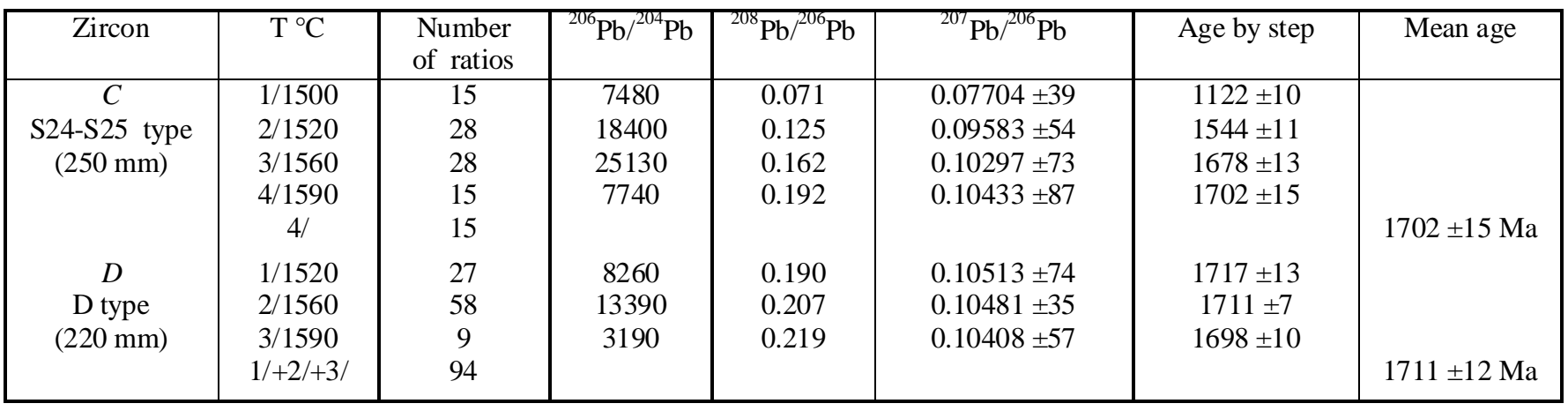
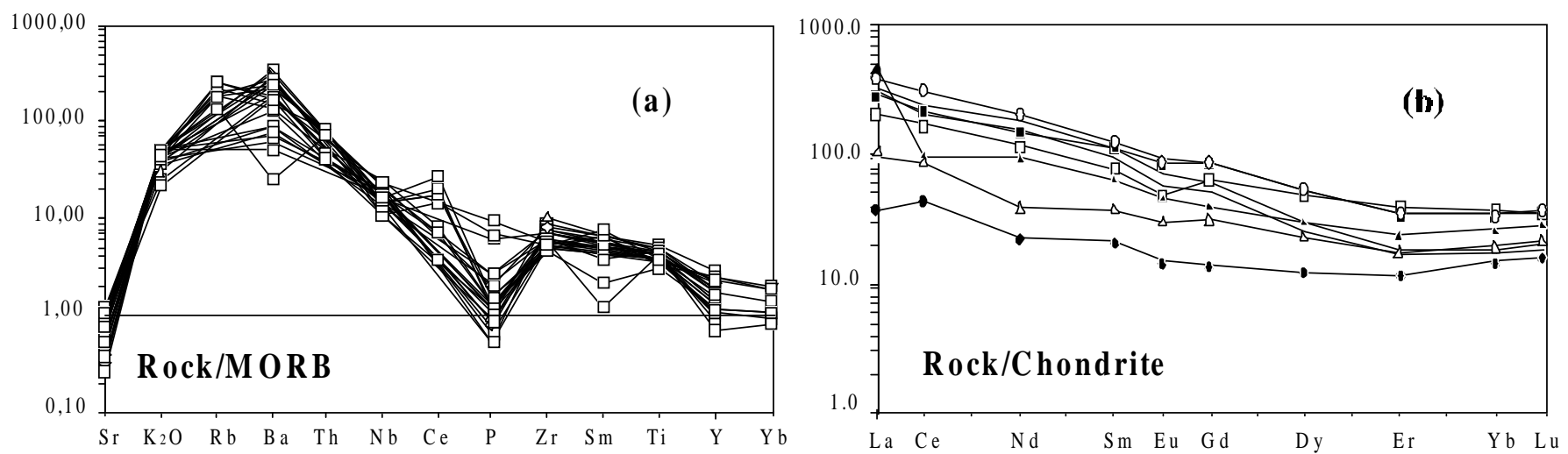

Figure 3 - Geochemical features of Fe-rich metavolcanics of the southern Espinhaço Range: (a) spider diagram, (b) rare earth elements diagram (modified from Dussin 1994).

CONCLUSIONS At ca. $1.7 \mathrm{Ga}$, the crust on the southeastern edge of the São Francisco Craton underwent a period of extension, with fracturing and formation of the Espinhaço rift. Alluvial fan and fluvial coarse-grained clastic sediments, locally accompanied by the magmatic protoliths of the $\mathrm{K}$ - and Fe-rich metavolcanics, characterized the onset of the sedimentation.

$\mathrm{The} \mathrm{Pb} / \mathrm{Pb}$ age, $1710 \pm 12 \mathrm{Ma}$, obtained by the geochronological study of the Fe-rich metavolcanics, dates the initial phases of the rift system. The age of the hematite phyllites indicates that this magmatism is broadly coeval with rhyolites juxtaposed with gneissic basement and Espinhaço metasediments along major mylonitic thrust zones in the eastern portion of the rift (Fig. 1). Geochronologic data for these rocks indicate ages between 1.77 and $1.71 \mathrm{Ga}(\mathrm{U} / \mathrm{Pb}$ determinations on zircon, according to Brito Neves et al. 1979 and Machado et al. 1989). These rhyolites are comagmatic with alkali-rich granites emplaced along major NS-extensional faults that cut the gneissic basement in regions adjacent to the rift at $1.73 \mathrm{Ga}(\mathrm{Pb} / \mathrm{Pb}$ age according to Dossin et al. 1993 and Dussin 1994). All these magmatic events denote the fracturing of the crust and thermal perturbation in the mantle at this time. Similar associations of continental basins, some with diamondbearing sediments and acid plutonism and volcanism are known in other parts of the Precambrian shield of Brazil.

Before the rifting phase, rocks of possible kimberlitic affinity intruded the upper crust in the regions west of the Espinhaço Range, as registered by the presence of diamonds in the Sopa Conglomerate. The clasts of this conglomerate indicate sources from other sedimentary rocks, with a small component from metamorphic and igneous rocks. However, mineralogical studies carried out by Chaves (1997) showed that kimberlitic and/or lamproitic indicators are missing.

The ages of zircons from this conglomerate here presented are interpreted as related to magmatic events that took place in the São Francisco Craton at 3.6, 2.8 and $2.0 \mathrm{Ga}$. The three generations of zircon populations shown by the radiometric ages clearly demonstrate the age of cratonic rocks, however is still unknown if one of them could be correlated with a primary source rock of the diamonds. The detrital zircons of the Sopa Conglomerate matrix are older than the primary zircons of the hematitic phyllites. Therefore, the geochronological data do not provide evidence for the idea that diamonds originated from these metavolcanic rocks, as supposed by some authors based on geologic regional studies (e.g. Herrgesell 1984, Almeida-Abreu 1993).

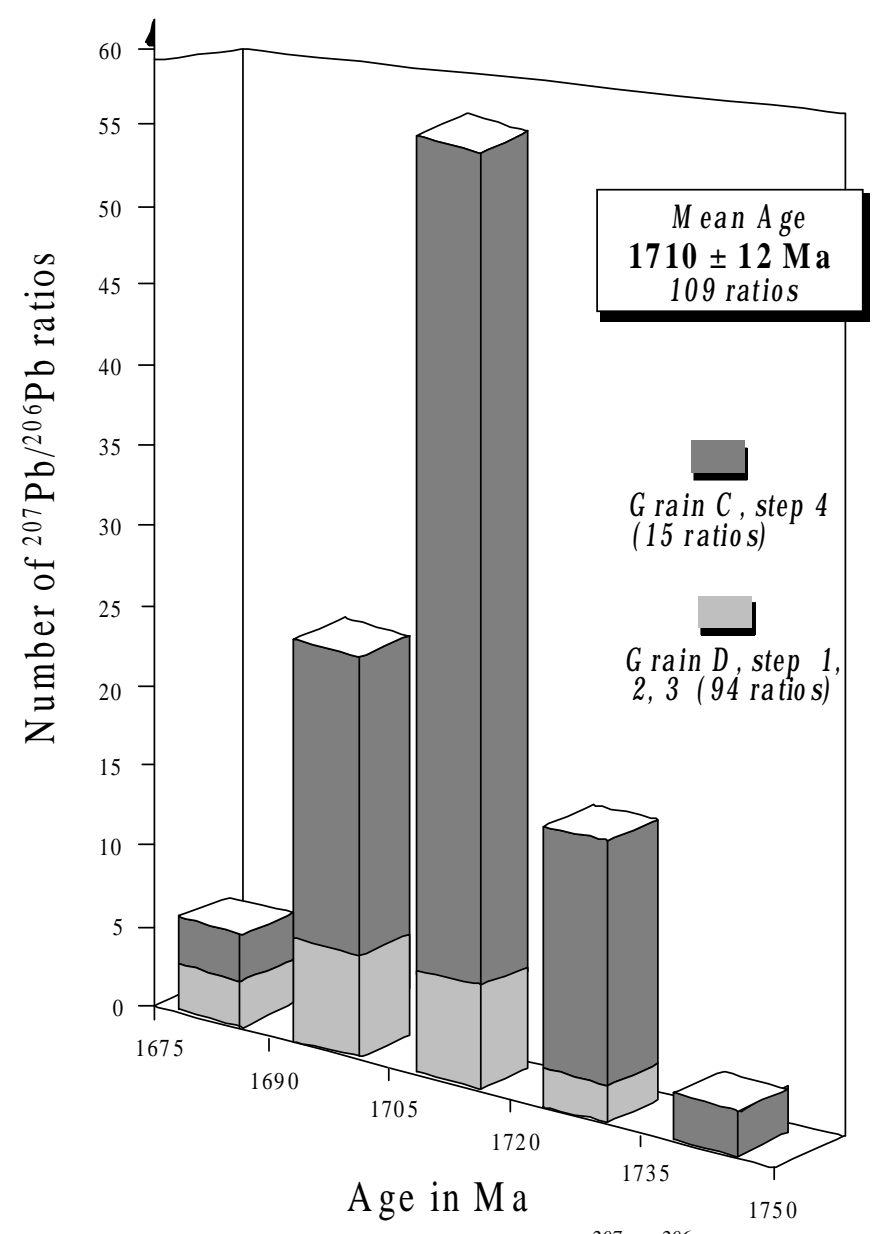

Figure 4-Histogram showing the distribution of ${ }^{207} \mathrm{~Pb} /{ }^{206} \mathrm{~Pb}$ ages versus number of ratios derived from evaporation of zircon grains from the Espinhaço Fe-rich metavolcanics. 


\section{References}

Almeida-Abreu. 1993. A evolução geodinâmica da Serra do Espinhaço Meridional, Minas Gerais, Brasil. Albert-Ludwigs-Universität, Freiburg, Tese de Doutoramento, 150 p

Brito Neves B.B., Kawashita K., Delhal J. 1979. A evolução geocronológica da Cordilheir do Espinhaco: dados novos e integracão. Rev. Bras. Geoc., 9:71-85.

Chaves M.L.S.C. 1997. Geologia e mineralogia do diamante da Serra do Espinhaço em Minas Gerais. IG/USP, São Paulo, Tese de Doutoramento, 289p.

Cocherie A., Guerrot C., Rossi P. 1992. Single-zircon dating by step-wise Pb evaporation: comparison with others geochronological techniques aplied to the Hercynian granites comparison with others geochronological techniques

Compston W., Williams I.S., Meyer C. 1984. U-Pb geochronology of zircons from lunar breccia 73217 using a sensitive high mass-resolution ion microprobe. J. Geophys.

Cullers R.L. \& Graf J.L. 1984. Rare earth elements in igneous rocks of the continental crust: predominantly basic and ultrabasic rocks. In: P. Henderson (ed) Rare earth element geochemistry, Developments on Geochemistry 2. Elsevier, 237-274.

Dossin I.A., Dossin T.M., Chaves M.L.S.C. 1990. Compartimentação estratigráfica do Supergrupo Espinhaco em Minas Gerais - os grupos Diamantina e Conselheiro Mata. Rev. Bras. Geoc., 20:178-186.

Dossin I.A., Dossin T.M., Charvet J., Cocherie A., Rossi P. 1993. Single-Zircon dating by step-wise $\mathrm{Pb}$-evaporation of Mesoproterozoic magmatism in the Espinhaco Range, southeastern São Francisco Craton (Minas Gerais, Brazil). In: Simp. Craton São Francisco, 2, Salvador, Anais, 39-42.

Dussin T.M. 1994. Associations plutono-volcaniques de l'Espinhaco méridional (SE-Brésil): un exemple d'évolution de la croûte protérozoique. Univ. Orléans, Doc. Thesis, $185 \mathrm{p}$

Garcia A.J.V. \& Uhlein A. 1987. Sistemas deposicionais do Supergrupo Espinhaço na região de Diamantina (MG). In: SBG/MG, Simp. Sistemas deposicionais do PréCambriano, Ouro Preto, 6:113-136.

Herrgesell G. 1984. Das Präkambrium am Ostrand der Nördlichen Serra do Cipó (Serra do Espinhaço, Minas Gerais, Brasilien). Albert-Ludwigs Univ.,Freiburg, Doct. Thesis, $247 \mathrm{p}$

Kober B. 1987. Single-zircon evaporation combined with $\mathrm{Pb}+$ emitter bedding for $207 \mathrm{~Pb} /$ $206 \mathrm{~Pb}$-age investigations using thermal ion mass spectrometry and implications for zirconology. Contrib. Mineral. Petrol., 96:63-71.
Ludwig K.R. 1998. Using Isoplot/Ex: A geochonological toolkit for Microsoft Excel. Berkeley, p.42 (Berkeley Geochronology Center Spec. Publ. 1).

Machado N., Schrank A., Abreu F.R., Knauer L.G., Almeida-Abreu P.A. 1989. Resultados preliminares da geocronologia U/Pb na Serra do Espinhaço Meridional. In: SBG, Simp. Geol. de Minas Gerais, 5, Belo Horizonte, Anais, Bol. 10:171-174.

Marshak S., Alkmin F.F. 1989. Proterozoic contraction/extension tectonics of the southern São Francisco region, Minas Gerais, Brazil. Tectonics, 8:555-571.

Müller D., Rock N.M., Groves D. 1992. Geochemical discrimination between shoshonitic and potassic volcanic rocks in different tectonic settings: a pilot study. Mineral. Petrol. 46:259-289.

Pflug R. 1968. Observações sobre a estratigrafia da Série Minas na região de Diamantina, Minas Gerais. Bol. DNPM/DGM 142, 20p.

Sano Y., Terada K., Yokochi R., Chaves M.L.S.C., Ozima M. 2000. Ion micropobe U-Th$\mathrm{Pb}$ dating of quartz inclusion in polycrystalline diamond. Geoch. Cosmoch. Acta (submmited).

Schobbenhaus C. 1993. O Proterozóico Médio no Brasil com ênfase à Região Centro-Leste. Freiburg, Albert-Ludwigs-Universität. Doct. Thesis, 166p.

Schöll W.U. \& Fogaça A.C.C. 1979. Estratigrafia da Serra do Espinhaço na região de Diamantina. In: SBG/MG, Simp. de Geologia de Minas Gerais, 1, Diamantina, Actas, 1:55-73.

Stacey J.S. \& Kramers J.D. 1975. Approximation of terrestrial lead isotope evolution by a two-stage model. Earth Planet. Sci. Lett., 26:207-221.

Tera F. \& Wasserburg G.J. 1972. U-Th-Pb systematics in three Apollo 14 basalts and the problem of initial Pb in lunar rocks. Earth Planet. Sci. Lett., 14:281-304.

Uhlein A. 1991. Transição craton - faixa dobrada: exemplo do Cráton do São Francisco e da Faixa Araçuaí (Ciclo Brasiliano) no Estado de Minas Gerais. Aspectos estratigráficos e estruturais. IG/USP, São Paulo, Tese de Doutoramento, 295p.

Uhlein A., Dossin I.A., Chaves M.L.S.C. 1986. Contribuição à geologia estrutural e tectônica das rochas arqueanas e proterozóicas da Serra do Espinhaço Meridional MG. In: SBG, Congr. Bras. Geol., 34, Goiânia, Anais, 3:1191-1203.

Contribution IGC-155

Received February 2, 2000

Accepted for publication April 30, 2000 